\title{
ANALYSIS FOR FINDING THE EFFECT OF MIND MAPPING TECHNIQUE ON THE IRANIAN ENGLISH AS FOREIGN LANGUAGE LEARNING' WRITING SKILLS
}

\section{ANÁLISE PARA DESCOBRIR O EFEITO DA TÉCNICA DE MAPEAMENTO MENTAL NAS HABILIDADES DE ESCRITA DA APRENDIZAGEM IRANIANA DE INGLÊS COMO LÍNGUA ESTRANGEIRA}

\author{
Bita Naghmeh-Abbaspour \\ Universiti Sains Malaysia, Malaysia \\ bitana@usm.my \\ Vahideh Rastgoo \\ Islamic Azad University, Iran \\ msn.sirjan2019@gmail.com
}

\begin{abstract}
Instructors are always interested in creating environments that motivate students to engage dynamically in their learning process. Mind mapping is one of the teaching and learning strategies that has emerged in this regard. The aim of this study was to determine the effect of mind mapping technique on the development of the organization of writing and learning of intermediate English as Foreign Language (EFL) language learners in Iran. Accordingly, thirty female intermediate English language learners were selected from a well-known institute in a small city as the participants of the study. They were randomly allocated to a control as well as an experimental group each consisting of 15 subjects. The control group was provided with the usual training, while the experimental group was presented with the intervention twice a week during the summer of 2019 . Pretest and posttest were applied for both groups in this experimental study and the results were then compared. Based on the research findings application of mind mapping in teaching writing could improve the learners' writing organization. However, it didn't show any significant effects on their writing style. As the results of the statistical analyses indicated, an application of mind mapping in writing classes would help the learners to organize their writings in more effective ways.
\end{abstract}

KEYWORDS: Mind mapping. Teaching writing. Writing organization. Writing style.

RESUMO: Os educadores sempre se interessaram pelo estabelecimento de ambientes que motivem e estimulem os alunos a se engajarem em seu processo de aprendizado de maneira ativa e dinâmica. O mapeamento mental está entre as estratégias de ensino e aprendizagem surgidas nesse sentido. Este estudo teve como objetivo determinar os efeitos que a técnica de mapeamento mental tem sobre o desenvolvimento da organização e estilo de escrita de alunos de Inglês como Língua Estrangeira iranianos intermediários. Assim, trinta participantes do ensino médio de inglês foram selecionadas de um instituto conhecido em uma pequena cidade como participantes do estudo. Eles foram alocados aleatoriamente para um controle, bem como um grupo experimental, cada um composto por 15 indivíduos. O grupo controle recebeu o treinamento usual, enquanto o grupo experimental recebeu a intervenção duas vezes por semana durante o verão de 2018. O pré-teste e o pós-teste foram aplicados para ambos os grupos neste estudo experimental e os resultados foram comparados. Com base nos resultados da pesquisa, a 
aplicação do mapeamento mental no ensino da escrita pode melhorar a organização de escrita dos alunos. No entanto, não mostrou efeitos significativos no estilo de escrita deles. Como os resultados das análises estatísticas indicaram, uma aplicação de mapeamento mental nas aulas de redação ajudaria os alunos a organizar seus escritos de maneira mais eficaz.

PALAVRAS-CHAVE: Mapeamento mental. Ensino de escrita. Organização da escrita. Estilo da escrita.

\section{Introduction}

It is generally recognized that the process of searching effective techniques and methods of teaching and learning will be successful provided that new techniques are established, while the old strategies are also rediscovered and empowered. The concept of employing the non-linear organization of thoughts is a good instance of a wellestablished strategy which can assist both teachers and students in classroom environment. In this regard, scholars have considered mind mapping as one of the most significant techniques that can be used in optimization of learning capacities and understanding of how the elements of complex structures are connected together (INGEMANN, 2017).

By definition, a mind map is a robust diagrammatic technique, presenting a complete scope of cortical skills in a single, strong manner. Mind mapping has been described as a visual, non-linear depiction of concepts and their associations (BIKTIMIROV and NILSN, 2006). In other words, mind maps support cognitive depth as one of the major learning strategies recommended by methodologists (BOROVKOVÁ, 2014). Mind maps can be applied in a variety of areas of academic learning by students. Mind mapping often appears in educational literature as employed in the learning of science concepts or with students who are learning English as their second (ESL) or foreign language (EFL); however, it seems to have advantages as an active and collaborative learning instrument in an extensive range of educational contexts.

Given the significant role of mind mapping in learning which has been investigated and demonstrated by different scholars of various fields, it could be a useful tool to be applied in learning English writing skill as well, especially considering the importance of planning prior to writing. Mind mapping is a strategy that can be applied by the students in the prewriting phase to plan, organize, associate and connect their ideas. Furthermore, mind mapping helps students to express their thinking in a recursive way, while it is a supportive technique in teaching and learning which allows students to develop their writing process since it is used as a pre-writing strategy (AL-JARF, 2011 as cited in VITULLI, 2016).

\subsection{Statement of the problem}

Challenges associated with the writing skills are among the most considerable and common problems influencing both native English speakers and also numerous students who are attempting to learn English as a second or foreign language across the globe. Writing is one of the skills whose command is essential to communicate in written form, while students usually tend to consider it as the most challenging skill (KHOIRIYAH, 2014). 
Furthermore, Al Kamli (2019, p. 1) asserts that "along with reading and understanding, writing is an indispensable part of the acquisition of a foreign language." Knowing the problems students face in writing and given the benefits mind mapping can bring in both teaching and learning, this research applies mind mapping as one of the pre-writing techniques to help language learners in two important aspects of writing skill including organization of their ideas and the style of their writing.

Mind mapping can play the role of a pre-writing strategy to assist learners in planning their ideas. Learners can use mind mapping strategy to develop any writing topic and it can be used with all types of paragraphs like narrative, descriptive, argumentative, expository etc. That is to say, this prewriting technique can deal with all types of paragraphs and can help learners explore topics in each type of writing (ABD KARIM et al. 2016 referred to RISWANTO; PUTRA, 2012). Mind maps are also beneficial for activating students' background knowledge about the topic. Harmer (2001 cited in KHUDHAIR, 2016, p. 430) stated that "using effective mind maps as classroom strategy can assist students to activate their prior knowledge and skills to apply to the writing task, and find out what information they already have and what they still need". Thus, the use of mind mapping as a prewriting strategy in EFL classroom is valuable because it motivates learners' thinking and creativity. When trying to collect new information, learners reveal the use of their background knowledge and link it with the new knowledge. Hence, by the use of mind maps, learners can write down their ideas logically in a visual scheme and develop their writing topic into a paragraph until to reach a desired number of ideas.

\subsection{Objectives of the study}

Consequently, the objective of this research is to investigate the effect of mind mapping on the development of intermediate Iranian EFL learners' writing skills in the following areas:

- Organizing the idea in chronological order

- Style of writings.

\subsection{Research questions}

According to the objectives of the study mentioned above, the following questions were raised:

Q1. Does mind mapping indicate a significant impact on the development of Iranian intermediate EFL learners' writing organization?

Q2. Does mind mapping indicate a significant impact on the development of Iranian intermediate EFL learners' writing style?

\subsubsection{Research hypotheses}

The following hypotheses were raised in the present research given the research objectives and questions:

H1. Mind mapping does not indicate a significant impact on the development of 
intermediate Iranian EFL learners' writing organization.

H2. Mind mapping does not indicate a significant impact on the development of intermediate Iranian EFL learners' writing style.

\section{Literature review}

Buzan (1976), the British psychologist, states that traditional methods postulate that the reader should scan the information from left to right and from the top to bottom, while the brain would rather scan the complete page in a non-linear manner. He also speculated extensively about the cerebral hemispheres in order to advocate the exclusive application of mind mapping over other methods of note-making. This concept is the basic principle of mind mapping. A Mind map is an illustrative, networked method for storage, organization, and prioritization of information, which is often done on paper, with the use of key words and pictures, each of which will 'snap on' special memories and stimulate new thoughts and concepts. Each memory trigger in a Mind Map is a key to discovery of facts, ideas, and knowledge and, also, to realization of the real capabilities of humans' extraordinary minds (BUZAN, 2006; cited in NOURI MOHAMMED, 2013).

All mind maps have several features in common. First of all, all of them have an idea or a central concept which is focused as a central image. The next common feature of mind maps is that their main theme radiates outwards from the central depiction as branches. Each branch consists of a key picture, key word, or special value built into the associative line. This line can be spatially organized like one point of a city land mark to another point in the city. Topics of less importance can be represented as sub-branches. Each branch contains and connects a modal structure connected to the whole structure (BURNS, 2014).

In general, a simple template of mind map with the above characteristics can be indicated as follows:

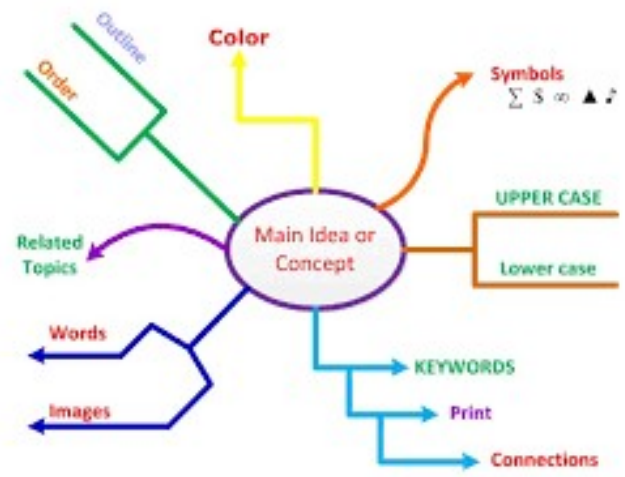

Figure 1: Overall representation of mind maps. Source: from the authors.

In recent years, scholars have started focusing on this technique in order to investigate its effects and applications in teaching different areas of knowledge including languages. Accordingly, the application of mind mapping has been examined from different dimensions such as its effectiveness in learning vocabulary, improving writing skills, and 
enhancing reading comprehension.

\subsection{Empirical studies in a global context}

Several studies have been performed in the global context regarding mind mapping and its association with learning different skills in the language learning process. This concept doesn't seem very old and most of the studies have been conducted during 21st century in some countries including UAE, Turkey, Scotland, etc. In the following paragraphs some of the studies which have focused on mind mapping and writing skills, particularly organization and style, are mentioned chronologically.

Al Naghbi (2008) in a study with the topic of application of mind mapping to improve writing skills in UAE schools investigated the female grade 11 EFL learners at the ages of 16 to 17 years in order to help students in grade 11 proceed from a product-based strategy toward a process-concentrated technique of writing and also to investigate the application of mind mapping in these conditions as a pre-writing brainstorming technique in the EFL context. The primary results indicated the application of mind mapping was accompanied by a considerable improvement in the students' writing and helped them to be more dynamic and also begin to learn different skills such as raising questions in order to grasp the assigned writing topics. They also learned to produce their own ideas for different writing tasks.

Karimatul Fajri (2011) investigated the improvement of the students' writing skill by applying mind maps on a group of tenth-grade students. The research aimed at finding out if mind mapping could help the students to promote their skill in writing personal restatement of text comprising the skill in organization of the idea in time arrangement, development of ideas, employing accurate grammar, particularly application of past tense, using accurate mechanism consisting of spelling, punctuation, as well as capitalization, and finally application of suitable and desirable arrangement of words along with expressions to strengthen the writing. The results of the study indicated that the students' writing skill developed after application of mind maps in teaching writing. The writer concluded that mind maps could affect teach writing.

Another study which was performed by Saed and Al-Omari (2014) on the influence of a program recommended according to a mind mapping technique in development of writing attainment of eleventh grade EFL students in Jordan including 91 female students in the first semester of the academic year of 2013/2014 at Sands National Academy, Amman Second Directorate of Education. The results indicated that students employing mind mapping to arrange and provide a summary of information in their writing draft could generate more rearrangements of ideas in their texts compared to the students who did not apply this technique. Mind mapping provided the learners with the chance to unify their ideas before writing. The students' potential to convey the meaning to write summaries developed remarkably and they could provide more comprehensive as well as wellorganized writings.

Erdiana (2016) investigated improvement of students' writing skill by means of mind mapping and tried to examine if application of mind mapping could promote the students' writing abilities at Secretary Class of LP3I College, Banda Aceh. Writing skill employed in this study was focused on how students were able to generate and organize idea and write 
well two types of business letters (making an inquiry and replying to inquiry letter). The findings proved that the application of mind mapping in writing business letters was effective since the students' results of writing from cycle one had improved in cycle two and the students' understanding of the writing concept got improved as well. The results from students' writing tests showed that $78 \%$ of students (above the determined criteria of success) improved their writing ability.

Aljaser (2017) in a study on the efficiency of electronic Mind Maps in development of academic achievement and the attitudes regarding learning English in primary school students aimed at identifying the impacts of applying electronic Mind Maps on the academic success of the fifth-grade primary female students in the English language curriculum in comparison with the traditional teaching procedures provided in the teacher's guide. Furthermore, the perspectives of the fifth-grade female students regarding the application of electronic Mind Maps in figuring out the study unit were also examined in this study. The study employed the quasi-experimental procedure which was applied to two groups: experimental and control. The study concluded that significant statistical differences could be found between the mean scores of the experimental group and the control one in the post achievement test scale which favored the experimental group. The effect size of the use of Mind Maps was high. Significant statistical differences could be found between the mean scores of the experimental and control group scores in the post achievement test regarding the students' perspectives on learning English in favor of the experimental group.

Al Kamli (2019) investigated "The Effect of Using Mind Maps to Enhance EFL Learners' Writing Achievement and Students' Attitudes towards Writing at Taif University", proposing the use of mind mapping strategy not only to organize ideas, but also to organize grammatical and linguistic knowledge. This study has examined the impacts of employing this mind mapping technique as a pre-writing procedure to improve female language learners' writing achievement as well as their perspectives considering writing in English at Taif University, Saudi Arabia. In a quasi-experimental design, a mixed methods approach was used through collection of quantitative as well as qualitative data. The study population included 128 students in an experimental and a control group. According to the finding of this study, first of all, differences were found between the mean scores of the experimental and the control groups on the post-tests of the students ' writing achievement and writing attitudes, which favored the experimental group; second, a significant difference was reported between the mean scores of the experimental group's pre- and post-tests in writing achievement and writing attitudes, in favor of the post-test; third, students' problems in writing in English consisted of the lack of vocabulary, organization, spelling as well as grammar; fourth, students were accustomed to memorization, practice, and self-correction, which indicated that they were not used to planning their writing; finally, students also showed positive perceptions regarding mind mapping strategy and believed it was helpful for them to improve their writings in English.

Lanseur and Haddouche (2019) studied the "Enhancing EFL Students' Writing Skill through Mind Mapping Strategy" in which they have asserted that most students consider writing as a hard task because they face difficulties in getting started and in organizing their ideas. The research sought to examine the association of mind mapping with the students' writing skill. This study aimed at examining the effects of mind mapping as a prewriting strategy on enhancement of the EFL students' writing skill. Toward this objective, a pre-experimental study was carried on. To test the hypothesis, the researchers used a pre- 
experiment study based on both quantitative method (pre-posttest, pre-post questionnaire) and qualitative method (textual analysis) of data collection. The participants included 18 bachelor science students in High courses private school. The results obtained confirmed the hypothesis, indicating that the participants experienced an improvement in their writing skill.

Mingli (2019) examined "Using Mind Maps to Develop English Majors' Essay Writing in China" in which essay writing was introduced crucial for Chinese English majors for the requirements of the TEM-4 (Test for English Majors-Band 4) and TEM-8. The author stated that many students are weak in essay writing because they use Chinese thinking patterns and structures to express their ideas, and lack frequent and sufficient writing practice. The study has examined the concepts of mind mapping in writing and supported their application in essay writing from word-level to whole essay structure by visual mind maps in order to stimulate their creativity in English essay writing effectively.

O'Hara and Budiyono (2019) used a classroom action research design to identify the improvement of argumentative essay scores of eleventh graders of Elyon Christian School Surabaya in the 2013/2014 academic year through mind mapping. Furthermore, the study was also carried on to provide a description of the process of teaching writing through application of mind maps to the eleventh graders. The data were collected by providing pre-tests, cycle process and post-tests. The results of the study showed improvements in the students' argumentative essay scores. It could be observed at the average scores of the pre-test (62.5) and post-test (85.5). The research process lasted for six weeks for completion, or twelve classroom meetings. It was also found that the students followed the teaching-learning process well and they represented interest in the lesson. According to the analyses, it was concluded that the eleventh graders of Elyon Christian School Surabaya developed their argumentative essay writing score by the use of mind mapping technique.

In total, according to the studies some of which were reviewed above, it was clear that in the global context most of the research has been carried out with emphasis on the effects of mind mapping on writing skills of students in schools and universities. It should be noted that all these studies have emphasized on the meaningful effects of mind mapping on the writing skills. The interesting common conclusion in all the mentioned studies is that mastery on mind mapping has helped the participants to develop writing skills and achieve higher gains in writing. Accordingly, as the studies indicate, understanding and communication of ideas take place easier and in a more natural as well as meaningful way using mind mapping.

\subsection{Empirical studies in the local context}

Studies in the context of mind mapping and English education in Iran do not indicate a long history and it seems that this topic has recently attracted the attention of Iranian scholars to itself. Unfortunately, there are limited studies on the topic of mind mapping and language learning in Iran, and it can be even observed that just a few studies have concentrated on mind mapping and writing skills among Iranian language learners. Two more related articles are mentioned here:

Nemati, Jahandar and Khodabandehlou (2014) in their paper on the influence of mind mapping on the improvement of advanced Iranian EFL learners' essay writing 
abilities via arrangement of information as well as thoughts have tried to study the influence of application of mind mapping in the role of a pre-writing aid on improvement of organization (as the major objective) and the total quality of Iranian EFL learners' essay writing efficiency at the advanced level. The study was performed on 40 EFL students divided into an experimental as well as a control group. During the intervention period, participants of the study learned how to create mind maps to generate ideas, connect them by the means of codes, colors as well as pictures and eventually providing a wellstructured writing. Their results indicated enhancement of the essay writing abilities in the experimental group.

Jafari and Zarei (2015) studied the impact of concept mapping on Iranian intermediate EFL learners' argumentative essay writing skill where they used an experimental procedure among 60 adult EFL learners from a language institute in Isfahan, Iran. The results indicated that instruction affected the students' essay writing skill significantly in the experimental group. On the other hand, no remarkable changes were reported for the participants of the control group. According to the results of this study, it was concluded that concept mapping strategy instruction is much influential in promoting students' argumentative essay writing.

Haji Maibodi (2017) studied the impact of mind mapping strategy on vocabulary use in the writing of Iranian EFL learners in which 60 pre-intermediate female students from two intact classes were selected from an English language institute in Ardakan, Yazd. At the instructions to both groups, the results of the post-test obtained through the SPSS software indicated that the experimental group outperformed the control group. The results of the delayed post-test conducted after a month revealed that the long term effect of the mind mapping strategy was significantly effective in the improvement of vocabulary used in writing tasks of EFL learners participating in the experimental group.

As it was mentioned before, since these studies are new in Iran, there is a lot of space to perform new studies and continue the previous research in order to generalize the existing findings.

\section{Research method}

\subsection{Participants}

The population of this study consisted of 30 language learners of a well-known institute, who had an intermediate level of English proficiency and whose level had been determined through placement tests of the institute. They were all female and in the age range of 15 to 20 years old. Before the study was performed, the researcher had a meeting with the language learners in the institute in which she explained the objectives and the procedures of the study. After providing sufficient information, they were asked to participate voluntarily in the research project and they were also ensured about the confidentiality of the results. The subjects were divided into two groups including 15 participants in each group. One of the classes was assigned to control group in which no intervention was provided. The second group served as the experimental group which received the intervention in order to be compared with the control group. The classes started in summer because the students of schools and universities are free and can participate in leisure time classes more conveniently. 


\section{DATA COLLECTION}

An experimental research design was applied in the present research to answer the research questions. Data collection was performed in three phases including pre-test, during the course, and post-test. Before the intervention, the pretest was applied for and experimental as well as control groups. They received identical writing pretest which asked them to write a paragraph. The essay length and essay components related to the tasks and skills were specified in the test instructions. Two raters graded these writing tasks in order to achieve higher reliability. If the average was the same, teaching could be started. Quizzes were frequently given to the learners during the experiment, and post-test, again learners were asked to write on a specific topic and all the writings were reviewed and graded by two raters after which the two groups were compared.

Measurement of students' scores was performed through the scoring rubric which was taken from Brown (2004, p. 243) and whose two aspects which were the focus of the present article are represented here:

Table 1: The Scoring Rubric.

\begin{tabular}{|c|c|c|c|c|c|}
\hline Aspect & $\begin{array}{l}\text { 20-18 (Excellent } \\
\text { to Good) }\end{array}$ & $\begin{array}{l}17-15 \text { (Good to } \\
\text { Adequate) }\end{array}$ & $\begin{array}{l}14-12 \text { (Adequate } \\
\text { to Fair) }\end{array}$ & \multicolumn{2}{|c|}{$\begin{array}{l}11-6 \\
\text { Unacceptable - Not college-level work }\end{array}$} \\
\hline 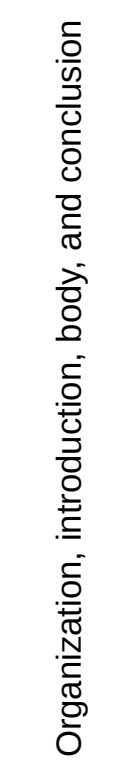 & $\begin{array}{l}\text { Suitable title, } \\
\text { efficient } \\
\text { introduction, } \\
\text { topic is } \\
\text { mentioned, } \\
\text { results in body; } \\
\text { transition } \\
\text { statements } \\
\text { applied, } \\
\text { organization of } \\
\text { materials } \\
\text { indicates } \\
\text { planning; } \\
\text { supporting } \\
\text { details provided } \\
\text { to generalize. }\end{array}$ & $\begin{array}{l}\text { Suitable title, } \\
\text { introductory, and } \\
\text { concluding parts; } \\
\text { body of writing is } \\
\text { admissible but } \\
\text { there may be lack } \\
\text { of some evidence, } \\
\text { development of } \\
\text { some ideas isn't } \\
\text { complete; } \\
\text { sequence is } \\
\text { rational but } \\
\text { transition } \\
\text { statements may } \\
\text { be missing or not } \\
\text { used properly. }\end{array}$ & $\begin{array}{l}\text { Ordinary or } \\
\text { insufficient } \\
\text { introductory or } \\
\text { concluding parts; } \\
\text { problems in } \\
\text { arrangement of } \\
\text { thoughts in body; } \\
\text { the generalization } \\
\text { is not completely } \\
\text { supported by the } \\
\text { evidence } \\
\text { provided; } \\
\text { problems of } \\
\text { arrangement } \\
\text { intervene. }\end{array}$ & $\begin{array}{l}\text { Weak or partially } \\
\text { specified } \\
\text { introductory part; } \\
\text { organization can } \\
\text { hardly be observed; } \\
\text { significant problems } \\
\text { in arrangement of } \\
\text { thoughts; } \\
\text { supporting details } \\
\text { are absent; } \\
\text { conclusion is poor } \\
\text { or irrational; } \\
\text { insufficient } \\
\text { endeavor to } \\
\text { organize. }\end{array}$ & $\begin{array}{l}\text { Missing } \\
\text { introductory or } \\
\text { concluding } \\
\text { parts; no clear } \\
\text { arrangement of } \\
\text { body; } \\
\text { supporting } \\
\text { details are } \\
\text { seriously } \\
\text { absent; writer } \\
\text { has not tried to } \\
\text { arrange the } \\
\text { text. }\end{array}$ \\
\hline
\end{tabular}


Belo Horizonte, v. 13, n. 2, p. 102-116, mai.-ago. 2020 - ISSN 1983-3652 DOI : $10.35699 / 1983-3652.2020 .24559$

\begin{tabular}{|c|c|c|c|c|c|}
\hline 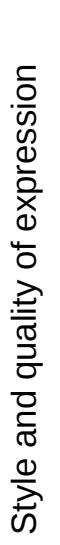 & $\begin{array}{l}\text { Exact use of } \\
\text { words; } \\
\text { employment of } \\
\text { parallel } \\
\text { structures; brief, } \\
\text { consistency } \\
\text { acceptable }\end{array}$ & $\begin{array}{l}\text { Uses diversity; } \\
\text { good words; not } \\
\text { wordy; } \\
\text { consistency ok; } \\
\text { style relatively } \\
\text { brief }\end{array}$ & $\begin{array}{l}\text { Improper use of } \\
\text { words; missing } \\
\text { attention to } \\
\text { consistency; } \\
\text { maybe too wordy }\end{array}$ & $\begin{array}{l}\text { Improper statement } \\
\text { of ideas; problems } \\
\text { in words; } \\
\text { insufficient diversity } \\
\text { in structure }\end{array}$ & $\begin{array}{l}\text { inconsistent } \\
\text { employment of } \\
\text { words; not } \\
\text { concept of } \\
\text { consistency or } \\
\text { sentence } \\
\text { variety }\end{array}$ \\
\hline
\end{tabular}

Source: from the authors.

Since this research was an experimental one that used an interval scale, the data were analyzed by using independent T-Test to calculate the pre- as well as post-test results.

\section{Results}

\subsection{Research implementation}

The research was conducted on 30 intermediate learners of English in two phases including a pretest and posttest. The initial data required for the study were collected from the pretest which was applied before the start of the study and the means of the scores in each component were calculated and presented in a table. Then both groups had 20 sessions of writing class with the difference that the control group received conventional teaching, while the experimental group received mind mapping technique as the intervention. After the determined period of the study, the posttest was applied for both groups and the mean scores were again recorded in tables. It should be emphasized that the writings were corrected by two correctors including the researcher and the observer.

\subsection{Scoring and addressing reliability concern}

As it was mentioned before, to ascertain the reliability of the scoring procedure, a research assistant was asked to evaluate the given scores to the students. The researchers' scores were compared against the assistant's scores. Thus, inter-rater reliability was calculated and exceeded 89\%. According to Creswell (1995), this is considered to be within the highest range of inter-rater reliability. Thus, for the subsequent analyses reported below, the researchers' scores were used as the basis of the analysis.

\subsection{Results of the pre-test}

Table 2 represents the descriptive statistics for the pre-test for the experimental as well as control group. As shown in the Table the scores were similar in both groups. 
Belo Horizonte, v. 13, n. 2, p. 102-116, mai.-ago. 2020 - ISSN 1983-3652 DOI : $10.35699 / 1983-3652.2020 .24559$

Table 2: Descriptive statistics of pre-test on students' performance on different aspects of writing.

\begin{tabular}{lllll} 
& Groups of students & No. & Mean scores & SD \\
\hline \multirow{2}{*}{ Organization } & Control & 15 & 13.40 & 1.47 \\
\cline { 2 - 4 } & & & & \\
& Experimental & 15 & 13.86 & 2.01 \\
\hline \multirow{2}{*}{ Style } & Control & 15 & 13.53 & 2.08 \\
\cline { 2 - 4 } & Experimental & 15 & 12.8 & 0.91 \\
\hline
\end{tabular}

Source: from the authors.

In order to see if the scores of the students in experimental as well as control groups are statistically similar, the scores were compared pairwise, through conducting a series of independent T-tests. The relative statistics are shown in Table 3.

Table 3: Independent samples T-tests on students' performance on pre-tests.

\begin{tabular}{lccc} 
Aspects of writing & DF & T-value & Sig \\
\hline Organization & 28 & 0.11 & 0.26 \\
\hline Style & 28 & 0.43 & 0.09 \\
\hline
\end{tabular}

Source: from the authors.

In order to see the treatment effects on students' scores in the post-test their scores were calculated. As Table 4 shows, the experimental group achieved higher scores.

Table 4: Descriptive statistics of post-test on students' performance on different aspects of writing.

\begin{tabular}{|c|c|c|c|c|}
\hline Aspects of writing & Groups of students & No. & Mean scores & SD \\
\hline \multirow{2}{*}{ Organization } & Control & 15 & 14.33 & 1.29 \\
\hline & Experimental & 15 & 15.26 & 1.27 \\
\hline \multirow{2}{*}{ Style } & Control & 15 & 13.93 & 1.38 \\
\hline & Experimental & 15 & 13.86 & 1.18 \\
\hline
\end{tabular}

Source: from the authors.

As the following table indicates, a meaningful difference was found in the students' scores in experimental and control for organization; however, the difference between the two groups regarding style was not significant. This means that the treatment did not show a significant impact on the style of students' writing performance. 
Table 5: Independent samples T-tests on students' scores in post-tests.

\begin{tabular}{lccc} 
Aspects of writing & DF & T-value & Sig \\
\hline Organization & 28 & 1.98 & 0.05 \\
\hline Style & 28 & 0.141 & 0.89 \\
\hline
\end{tabular}

Source: from the authors.

\section{Discussion and conclusion}

\subsection{Discussion}

The data indicate that the application of mind mapping technique has improved the learners' scores in organizing writings. This was proven by the mean of posttest which was higher than the mean of pretest in the experimental group. This finding is also supported by the results of data analysis from the questionnaire that showed most students responded positively to this technique. The results of this study are in line with the findings of several other studies which have been performed in similar fields.

The results obtained in this study are in line with the findings of the study performed by Karimatul Fajri (2011) in which it was shown that mind mapping could promote the students' efficiency to organize their texts. In the same line, Saed \& AL-Omari (2014) concluded that mind mapping provided students with the chance to unify their thoughts before writing and was therefore effective in improvement of organization of their ideas. This finding is again consistent with the present research. In a more recent study, Al Kamli (2019) concluded that students lacked organization as one of the problems in writing. He found that mind mapping technique could improve the learners' writing skills. Finally, Mingli (2019) has also stated that mind mapping could affect the structure of writing positively which is in line with the results obtained in this article. From the overall perspective of writing improvement, the results of the present study are consistent with the results of Lanseur and Haddouche (2019) and O'Hara and Budiyono (2019) who have come to the conclusion that mind mapping can improve writing skills in general. In the local context, the studies done by Nemati, Jahandar and Khodabandehlou (2014) and Jafari and Zarei (2015) have also referred to the positive impacts of mind mapping on students' writing aspects, particularly their organization of writing texts.

\section{Conclusion}

Considering the findings of the research and also the discussion, it can be said that mind mapping technique has helped the students organize their texts. Mind mapping could help students to develop their writing skills in terms of organizing ideas. Consequently, mind mapping would be especially suitable to assist students in planning their writing, since the technique stimulates them to obtain and establish a deeper understanding of the writing topics.

From the researcher's observations, it becomes clear that this procedure can be employed for a variety of tasks associated with learning how to write. According to the observations, students keep a variety of expectations as well as priorities, so that different 
students may be satisfied with various aspects of mind mapping. According to what has been shown, this strategy supports organization in learning and practicing writing skill. Nevertheless, it depends exclusively on teachers and their students to what extent they would handle the benefits of this technique. It can be particularly applied as the critical strategy of language teaching, or it can play the role of an occasional option to make a lesson more specific.

\section{Acknowledgement}

The authors would like to appreciate all participants of the study that patiently attended the classes and cooperated sincerely during the study period and provided her the possibility to complete the research. Furthermore, it should be acknowledged with much appreciation the crucial role of the second rater who collaborated in students' scoring.

\section{References}

AL-JARF, R. Teaching spelling skills with a mind-mapping software. Asian EFL Journal Professional Teaching Articles, 53,p. 4-16, 2011. Retrieved from http://70.40.196.162/PTA/Volume-53raj.pdf

ALJASER, A. M. The Effectiveness of Electronic Mind Maps in Developing Academic Achievement and the Attitude towards Learning English among Primary School Students. International Education Studies, v. 10, n. 12, 2017.

AL KAMLI, H. M. The Effect of Using Mind Maps to Enhance EFL Learners' Writing Achievement and Students' Attitudes Towards Writing at Taif University. (Master Thesis), Arab World English Journal (ID Number: 232), p. 1-92, 2019. DOI: https://dx.doi.org/10.24093/awej/th.232

AL NAGHBI, S. The use of mind mapping to develop writing skills in UAE schools, 2008. Retrieved from: https://www.emeraldinsight.com. Accessed on: 20 August 2018.

BIKTIMIROV, E. N.; NILSON, L. B. Show them the money: Using mind mapping in the introductory finance course. Journal of Financial Education, 32, p. 72-86, 2006.

BOROVKOVÁ, M. P. Application of mind maps in ELT with the emphasis in lexis. Unpublished MA Thesis: Charles University in Prague, Prague, 2014.

BROWN, D. H. Language assessment: principles and classroom practices. New York: Longman, 2003.

BURNS, B. Mind Mapping: 7 ways to use mind mapping as a developer, 2014. Retrieved from: https://www.netguru.co/blog/mindmapping-7-ways-to-use. Accessed on: 20 August 2018.

BUZAN, T. Use both side of your brain. New York: E.P. Dutton Co, 1976. 
CRESWELL, J. W. Research design: Qualitative and quantitative approaches. Thousand Oaks, CA: Sage, 1995.

ERDIANA, N. Improving Students' Writing Skill through Mind Mapping. Proceedings of the 1st EEIC Conference: Banda Aceh, Indonesia, 2016.

HAJI MAIBODI, A. The impact of mind mapping strategy on vocabulary use in the writing of Iranian EFL learners. Unpublished M.A. thesis. Islamic Azad University, Maybod Branch, 2017.

INGEMANN, M. The power of mind mapping. London: John Benjamin Publishers, 2017.

JAFARI, N.; ZAREI, GH. R. The influence of concept mapping on iranian intermediate EFL learners argumentative essay writing skill. Journal of applied linguistics and language research, 2, p. 98-112, 2015.

KARIMATUL FAJRI, A. Improving Students' Writing Skill by Using Mind Maps: A Classroom Action Research on the 10th Grade Students. Unpublished MA thesis Sebelas Maret University, 2011.

KHOIRIYAH. Increasing the students writing skills through mind mapping technique. Nusantara of Research, 1, (2), p. 14-21, 2014.

KHUDHAIR, N. K. The impact of applying mind mapping technique as a prewriting tool on EFL college students in essay writing. $J$ Of College of Education for Women. 27 (1), p. 426-436, 2016. Retrieved from: https://www.iasj.net/iasj?func=fulltext\&ald=117731. Accessed on: Mai 12th, 2019.

LANSEUR, K.; HADDUCHE, S. Enhancing EFL Students' Writing Skill through Mind Mapping Strategy. The People's Democratic Republic Of Algeria Ministry Of Higher Education And Scientific Research Abderrahmane Mira University Of Bejaia Faculty Of Arts And Languages Department Of English, 2019.

MINGLI, L. Using Mind Maps to Develop English Majors' Essay Writing in China. Sino-US English Teaching, v. 16, n. 10, p. 419-425, 2019.

NEMATI, A.; JAHANDAR, SH.; KHODABANDEHLOU, M. The effect of mind mapping technique on the enhancement of advanced iranian EFL learners' essay writing ability through organizing information and thoughts. Indian Journal of Fundamental and Applied Life Sciences, 7, p. 78-93, 2014.

NOURI MOHAMMED, A. Introducing the mind map technique to promote lesson summarizing in EFL instruction: Case study of first year IMD student of the English language. Unpublished PhD Dissertation at Mohamed Khieder University of Biskra University: Lampour, India, 2013.

O'HARA, D.; BUDIYONO, B. Using Mind Mapping to Improve Argumentative Writing Score 
Of Eleventh Graders. Magister Scientiae, 106 Edisi No. 45, 2019.

RISWANTO; PUTRA, P. P. The Use of Mind Mapping Strategy in the Teaching of Writing at SMAN 3 Bengkulu, Indonesia. International Jurnal of Humanities and Science, 2 (21), 6068, 2012.

SAED, H. A.; AL-OMARI, H. A. The effectiveness of a proposed program based on a mind mapping strategy in developing the writing achievement of eleventh grade EFL students in jordan and their attitudes towards writing. Journal of Education and Practice, 5, p. 88-109, 2014.

VITULLI, P.; GILES, R. Mind Mapping: Making Connections with Images and Color. Delta Journal of Education, 6(2), p. 1-10, 2016.

Recebido em dia 18 de junho de 2020. Aprovado em dia 07 de agosto de 2020. 